удК 342.5

DOI https://doi.org/10.32837/apdp.v0i85.1828

I. М. Длитрук

\title{
ПРАВОВІ ІНСТРУМЕНТИ ВПРОВАДЖЕННЯ ДЕЦЕНТРАЛІЗАЦІЇ В УКРАЇНІ
}

Децентралізація поряд з багатьма можливостями передбачає ключову з них самостійне прийняття рішень місцевою громадою. Це важливе завдання потребує високого рівня правосвідомості, осмислення того, що за власні дії потрібно буде нести відповідальність. Тому вкрай необхідним є закріплення низки правових інституцій, які допоможуть впроваджувати процеси самореалізації громади, становлення її самодостатності.

При проведенні наукового аналізу діючої нормативно-правової бази було виявлено відсутність важливих для місцевої громади нормативно-правових актів, які б дали змогу реалізувати їх конституційні права. Зокрема, це стосуеться закону про місцевий референдум. Саме цей правовий інститут допоможе жителям місцевої громади легітимізувати своє рішення та спонукає владу прислухатися до них.

Ще одним із важливих правових інструментів при побудові горизонтальних i вертикальних правовідносин, в яких суб’єктом є орган місцевого самоврядування, виступає адміністративний договір. Його часте використання відкриває значно кращу можливість у спрощенні надання адміністративних послуг територіальними громадами, покращує відносини між органами державної влади та місцевого самоврядування, усуває елементи бюрократії, не порушуючи при цьому правового статусу всіх суб’'єктів таких правових відносин.

Актуалізація досліджуваної теми зосереджується на вказаному правовому інструментарії, що допоможе громадам на теперішньому етапі впровадження децентралізації реалізувати окреслені цілі та сприяти покращенню добробуту.

Метою цієї статті є розкриття спірних питань впровадження місцевого референдуму, його правове врегулювання, укладання та виконання умов адміністративного договору з метою впровадження децентралізаційних процесів.

Порушену в статті проблематику вивчали науковці-юристи В. Авер'янов, О. Андрійко, С.С. Алексєєв, І.В. Алексєєв, Ю. Битяк, К. Бандурка, І. Бєльський, П.К. Бечко, Д. Бахрах, М. Бояринцева, А. Васильєв, Д.М. Веприняк, П.М. Годме, В. Гаращук, А. Демин, Е.С. Дмитренко, О. Іоффе, А. Кармолицький, М. Міхровська, М. Смокович, О. Панченко, О. Пасенюк, С. Резніченко, Р. Сінєльнік, Е. Старостяк, В. Стефанюк, Л.А. Савченко, Г.Г. Старостенко, А.О. Селіванов, А.Д. Селюков, Н.В. Сидорова, І.А. Сікорська, А.А. Тедеєв, Р.А. Усенко, Н.І. Хімічева, А.І. Худяков, С.Д. Ципкін та інші.

В Україні продовжують розвиватися непрості процеси децентралізації, активне впровадження яких дає об'єднаним територіальним громадам можливість набути бюджетних, фінансових та інших повноважень, що мають показово посприяти їх поступальному розвитку та ефективності. В такому контексті необхідно значно активніше впливати на впровадження правового інструментарію, який допоможе місцевій громаді ефективно реалізовувати покладені на неї функції.

(C) I. М. Дмитрук, 2020 
Досліджуючи цей аспект, авторка вважає за необхідне виділити такі інститути як місцевий референдум та адміністративний договір. Хоча це не виключає можливості існування інших ефективних форм і методів впливу на впровадження децентралізації. Загальновідомим фактом є те, що в нашій державі поки що не існує відповідного правового поля, яке б врегулювало інститут місцевого референдуму. Він залишився поза правом, хоча передбачений Конституцією України. Саме такий правовий інститут може стати досить впливовим фактором у подальшому системному впровадженні децентралізації. При цьому важливим залишається аргумент, коли в демократичній державі спільнота повинна мати власні важелі впливу на діяльність влади.

Правовим підгрунтям названої позиції є Розділ III Конституції України. Зокрема, в статті 69 документу вказується, що народне волевиявлення здійснюється через вибори, референдум та інші форми безпосередньої демократії . Відповідно до рішення КСУ від 16 квітня 2008 року № 6-рп-2008 правове регулювання порядку здійснення безпосередньої демократії, зокрема референдуму, спрямоване на те, щоб поєднати ці форми із способами та засобами, які характеризують представницьку демократію, доповнити їх, але не зробити конфліктними з можливою підміною парламенту референдумом (чи навпаки) [1].

Важливе значення інституту референдуму полягає в тому, що його проведення істотно наближає громадян до влади та суспільних справ, сприяючи активнішому їх залученню в складні процеси прийняття справжніх державницьких рішень, глибшому осмисленню очікуваних результатів. Пристальну увагу слід звернути на місцевий референдум як на правовий інститут, а не на політичний інструмент. Адже він дозволяє розв'язати кардинальні проблеми, що стоять перед громадою і відіграють ключове значення в її життєдіяльності.

На жаль, це право гарантоване Конституцією, але обмежене законодавцями для об’єднаних територіальних громад і громадян України, оскільки відсутній закон, який би врегулював порядок проведення місцевого референдуму. В українському суспільстві відчувається запит на більш активну участь в процесі державного управління народом. Можливо, існування спеціальної глибоко продуманої процедури проведення місцевих референдумів дало б змогу громадянам показати силу народовладдя, поступово знявши напружену суспільну агресію.

До того ж, установлене поняття децентралізації передбачає можливість місцевим жителям вирішувати юридичну долю своїх поселень, де вони проживають і працюють.

Місцевий референдум у визначеному контексті посідає особливе місце в системі правових інститутів безпосередньої демократії. Парламентська Асамблея Ради Європи у своїй Резолюції № 1121 (1997) «Про інструменти участі громадян у представницькій демократії» зазначила, що «узгодження в основному суперечливих і конфліктуючих вимог громадян або груп громадян, які продиктовані загальним інтересом, може бути досягнуто тільки через парламентські обговорення. Використання прямої демократії слід розглядати як доповнення. Навіть у Швейцарії, яка є прикладом країни в частині застосування прямої демократії, 95\% рішень приймаються парламентом». Вона закликала держави-членів Ради Європи «вдоскона- 
лити свою систему представницької демократії шляхом встановлення балансу між відповідальністю державної влади та роллю громадян у процесі прийняття рішень. За відсутності такого балансу буде не можливо запобігти як підриву впевненості у представницькій системі, так і непродуманому використанню частих референдумів, що робитиме проведення будь-якої довготривалої політики, заснованої на фундаментальних питаннях дискусії, безсистемним, неефективним або навіть не можливим» (пункт 6, підпункт 15.1) [2].

В Україні такий баланс урегульовано в сторону парламентаризму. Влада народу нівелюється шляхом відсутності необхідних інструментів для досягнення поставлених цілей, які передбачає децентралізація. Не можливо впроваджувати процеси децентралізації без розширення правових інструментів, які мають бути справедливо ввірені саме народу. Хоча можна передбачити чимало ситуацій, коли місцеві референдуми матимуть негативний вплив на державне управління. Основна з них полягає у послабленні через референдум представницького органу. Через що необхідно наголосити на важливості статті 5 Конституції України, яка визначає народ основним джерелом влади. Тому позбавлення його тих владних інструментів, які передбачені Конституцією, шляхом неприйняття відповідного закону, суперечить самому інституту парламентаризму, його основній ідеї.

Існує багато інших побоювань. Наприклад, низький рівень правової культури чи правосвідомості громадян, підміна або маскування понять у формулюванні питань, що вносяться на референдум, часте ініціювання референдуму та інше. Проте право, гарантоване Конституцією, ніхто не може забрати. Децентралізація не відповідатиме своїй суті без існування інституту місцевого референдуму в правовій площині. Референдум повинен існувати в демократичному суспільстві, адже він може бути використаний як противага рішенням органів державної влади та місцевого самоврядування, які інколи піддаються суперечливим мотиваціям найактивнішими громадянами.

Згідно окремої думки судді Конституційного Суду України В.М. Кампа від 16.04.2008 стосовно рішення КСУ у справі від 16.04.2008 № 6-рп-2008 щодо досягнення суспільного консенсусу, в основу якого покладено ідею народного суверенітету як основну ціль народовладдя, чітко виокремлюється, що саме народ є інструментом суспільного консенсусу, який полягає в досягненні громадянської згоди 3 найважливіших питань суспільно-політичного та правового життя. Народ є арбітром у конфліктах між органами державної влади, що виступають інструментами політичних інтересів та досягнення політичних компромісів [3].

У процесі децентралізації самодостатні громади потребують також договірного врегулювання правових відносин, що можуть скластися чи складатимуться в них з органами влади. Такий спосіб узгодження спірних питань і задоволення потреб громади є найдоцільнішим. Адміністративний договір яскраво виражає взаємозв'язок держави та громади.

Відповідно до пункту 16 статті 4 Кодексу адміністративного судочинства України від 06.07.2005 № 2747-IV адміністративний договір - спільний правовий акт суб’єктів владних повноважень або правовий акт за участю суб'єкта владних повноважень та інших осіб, що грунтується на їх волеузгодженні, має форму договору, угоди, 
протоколу, меморандуму тощо, визначає взаємні права та обов'язки його учасників у публічно-правовій сфері і укладається на підставі закону для розмежування компетенції чи визначення порядку взаємодії між суб'єктами владних повноважень; для делегування публічно-владних управлінських функцій; для перерозподілу або об’єднання бюджетних коштів у випадках, визначених законом; замість видання індивідуального акта; для врегулювання питань надання адміністративних послуг. Слід зазначити, що в цьому дослідженні адміністративний договір розглядається виключно як інструмент більш глибокого впровадження децентралізації.

Причиною виникнення адміністративного договору (особливо в сфері делегованих повноважень) може бути як закон, де чітко має бути встановлено умови таких правових відносин, так і рішення районної, обласної ради про делегування повноважень відповідними державними адміністраціями. Тут договір постає як необхідність врегулювання правових відносин між суб’єктами цих відносин, одним із яких є суб'єкт публічного права.

Правова природа таких договорів досить дискусійна. Особливістю адміністративного договору є його комплексний характер. Однозначно суб'єкти владних повноважень можуть діяти не лише згідно імперативного методу. В своїй діяльності вони здатні використовувати вільне волевиявлення, що стосуватиметься різних сфер діяльності такого суб'єкта. Необхідно зазначити, що адміністративний договір - це завжди вільне волевиявлення суб'єктів публічно-правових відносин у сфері державного управління, а адміністративний акт - це юридично владне волевиявлення суб'єктів публічно-правових відносин в односторонньому порядку.

Ще однією зі сфер правового врегулювання при укладанні адміністративного договору є перерозподіл компетенцій органів виконавчої влади та органів місцевого самоврядування, їх суб’єктного складу. Такий підхід допоможе місцевим громадам ефективно визначати порядок взаємодії між собою, дозволить їм чітко окреслити компетенції, які будуть прописані в подібному договорі. Це можна зробити як у формі меморандуму, так і у формі угоди чи визначення відповідних пунктів у протоколі, що буде трактуватися як укладання адміністративного договору.

Використовуючи необхідні та додаткові ознаки, до адміністративних договорів можна включати всі договори, що укладаються суб'єктом, який наділений владними управлінськими функціями на підставі законодавства для виконання його повноважень. Використання адміністративного договору прискорить ефективну діяльність територіальних громад та органів державної влади і надихне їх до значно оперативнішого втілення прийнятих рішень у життя.

Висновки. Досліджуючи цю проблему, авторка доходить висновку щодо необхідності розбудови механізму державного управління «по-українськи» 3 якнайповнішим використанням чи не найважливішого складника всієї управлінської системи - народовладдя. Історично складається так, що українська влада в усі часи, починаючи з віче Володимира Великого і завершуючи Майданом у XXI-му столітті, обмежувалася народним впливом.

Установча влада в нашій державі належить до виключного права українців, тому вкрай важливо найближчим часом прийняти Закон «Про місцеві референдуми», щоб реально ввести в українське правове поле ключовий інструмент демо- 
кратії та підкріпити норми Конституції не формальними положеннями, а дієвими кроками. При цьому слід рекомендувати органам місцевого самоврядування частіше використовувати адміністративний договір як правовий інструмент у процесі децентралізації. Це дасть змогу закріпити компетенції в окремих дискусійних ситуаціях і діяти в рамках правового поля.

Як показала практика, в критичних умовах центральна влада забуває про основні принципи децентралізації і бере управління в свої руки. Проте місцева влада уповноважена самостійно вирішувати питання життєдіяльності населених пунктів, не зважаючи на форс-мажорні обставини (стихійні лиха, епідемії, епізоотіі), інші виклики часу. Тому потрібно посилити вже існуючі правові інструментарії чи законодавчо закріпити нові для того, щоб надати можливість громаді захистити свої інтереси.

\section{Jimepamypa}

1. Рішення КСУ від 16 квітня 2008 року № 6-рп-2008 у справі за конституційними поданнями Президента України про офіційне тлумачення положень частин другої, третьої статті 5 , статті 69 , частини другої статті 72, статті 74, частини другої статті 94, частини першої статті 156 Конституції України (справа про прийняття Конституції та законів України на референдумі) / Офіційний вебпортал Верховної Ради України [Електронний ресурс]. - Режим доступу: https://zakon.rada.gov.ua/laws/show/ v006p $710-08$.

2. Висновок на проєкт Закону України «Про місцевий референдум» (реєстр № 2145а-3 від 08.07.15) / Офіційний вебпортал Верховної Ради України [Електронний ресурс]. - Режим доступу: http://w1.c1.rada.gov.ua/pls/zweb2/webproc4_1?pf3511=55941.

3. Окрема думка судді КСУ Кампа В.М. стосовно Рішення КСУ від 16 квітня 2008 року № 6 -рп-2008 / Офіційний вебпортал Верховної Ради України [Електронний ресурс]. - Режим доступу: https://zakon.rada.gov.ua/laws/show/nb06d710-08\#n2.

4. Кодекс адміністративного судочинства України від 06.07.2005 № 2747-IV / Офіційний вебпортал Верховної Ради України [Електронний ресурс]. - Режим доступу: https://zakon.rada.gov.ua/laws/ show/2747-15.

\section{Анотація}

Дмитрук І. М. Правові інструменти впровадження децентралізації в Україні. - Стаття.

Досліджується впровадження та посилення таких правових інститутів, як місцевий референдум та адміністративний договір на теперішньому етапі децентралізації в Україні. Проводиться аналіз нормативно-правової бази, в результаті якого формуються висновки про відсутність достатнього правового регулювання місцевого референдуму, що суперечить нормам Конституції України.

Референдум повинен існувати в демократичному суспільстві, адже він може бути використаний як противага рішенням органів державної влади та місцевого самоврядування, які інколи піддаються суперечливим мотиваціям найактивнішими громадянами. Місцевий референдум допоможе жителям громади легітимізувати свої рішення безпосередньо. Установча влада в Україні належить до виключного права українців, тому найближчим часом необхідно прийняти Закон «Про місцеві референдуми», щоб ввести в українське законодавство ключовий інструмент демократії та підкріпити норми Конституції не формальними положеннями, а дієвими кроками.

Адміністративний договір, як інструмент договірного врегулювання правових відносин, що можуть скластися чи складатимуться з органами влади та територіальною громадою, потребує частішого використання на практиці. Причиною виникнення адміністративного договору може бути як закон, де чітко мають встановлюватися умови таких правових відносин, так і рішення ради про делегування публічно-владних управлінських функцій для розмежування компетенції чи визначення порядку взаємодії між суб'єктами владних повноважень, для перерозподілу або об'єднання бюджетних коштів у випадках, визначених законом, замість видання індивідуального акта для врегулювання питань надання адміністративних послуг. 
Тут договір постає як необхідність врегулювання правових відносин між суб'єктами цих відносин, одним із яких є суб'єкт публічного права. Правова природа таких договорів є досить дискусійною. Використання адміністративного договору прискорить ефективну діяльність територіальних громад $\mathrm{i}$ органів державної влади та надихне їх до значно оперативнішого впровадження прийнятих рішень у життя. Не можливо впроваджувати процеси децентралізації без розширення правових інструментів, які мають бути справедливо ввірені саме народу.

Ключові слова: територіальна громада, місцевий референдум, адміністративний договір, публічно-владні функції, адміністративні послуги.

\section{Summary}

Dmytruk I. M. Legal instruments for the implementation of decentralization in Ukraine. - Article.

The introduction and strengthening of such legal institutions as a local referendum and an administrative agreement at the current stage of decentralization in Ukraine is studied. An analysis of the legal framework is carried out, as a result of which conclusions are drawn about the lack of sufficient legal regulation of the local referendum. This contradicts the norms of the Constitution of Ukraine. A referendum must exist in a democratic society, as it can be used as a counterweight to the decisions of public authorities and local governments, which are sometimes subject to conflicting motivations by the most active citizens.

The local referendum will help community residents legitimize their decisions directly. Constituent power in Ukraine belongs to the exclusive right of Ukrainians. Therefore, in the near future it is necessary to adopt the law "On local referendums" in order to introduce into Ukrainian legislation a key instrument of democracy and to support the provisions of the Constitution not with formal provisions, but with effective steps.

Administrative contract, as an instrument of contractual settlement of legal relations that may or will be formed with the authorities and the territorial community needs to be used more often in practice. The reason for the administrative agreement may be both the law, which must clearly establish the terms of such legal relations, and the decision of the council to delegate public authority, to delimit the competence or determine the order of interaction between the subjects of power, for redistribution or pooling of budget funds in cases specified by law, instead of issuing an individual act, to regulate the provision of administrative services.

Here, the contract appears as a necessity to regulate legal relations between the subjects of these relations, one of which is a subject of public law. The legal nature of such agreements is quite debatable. The use of an administrative agreement will accelerate the effective activities of territorial communities and public authorities and lead them to much more rapid implementation of decisions. It is not possible to implement decentralization processes without expanding the legal instruments that must be justly entrusted to the people.

Key words: territorial community, local referendum, administrative agreement, public authority functions, administrative services. 